\title{
Initiation Condition of Hemodialysis Is Independently Associated with All-Cause Mortality in Maintenance Hemodialysis Patients: A Retrospective Study
}

\author{
Chang Wang ${ }^{a, b}$ Yuan Yang ${ }^{a, c}$ Fang Yuan ${ }^{a, b}$ Hui-Qiong Li ${ }^{a, b}$ Li-Yu He $^{a, b}$ \\ Di Liu ${ }^{a, b}$ Ye-Xin Liu ${ }^{a, b}$ An Zhou ${ }^{a, b}$ Xing Chen ${ }^{a, b} \quad$ Fu-You Liu ${ }^{a, b}$ \\ You-Ming Peng ${ }^{a, b}$ Hong Liu ${ }^{a, b}$ \\ a Department of Nephrology, The Second Xiangya Hospital, Central South University, Changsha, China; ${ }^{\mathrm{b}}$ Institute of

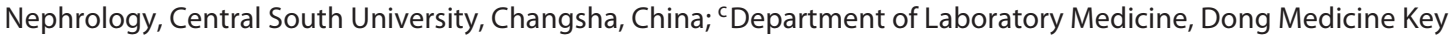 \\ Laboratory of Hunan Province, Hunan University of Medicine, Huaihua, China
}

\author{
Keywords \\ Maintenance hemodialysis · Survival analysis $\cdot$ Risk factors
}

\begin{abstract}
Background: Despite the progression of dialysis techniques, the mortality of hemodialysis (HD) patients is still high in China. Here, a retrospective study was performed to investigate the neglected risk factors of all-cause mortality during maintenance HD (MHD). Methods: We investigated 117 MHD patients who died between 2011 and 2016 in the Second Xiangya Hospital of Central South University HD center. In order to analyze the risk factors of 48 months all-cause death, the methods of Kaplan-Meier and Cox regression were used. Results: Multivariate analyses of adjusted age and gender showed that MHD patients with estimated glomerular filtration rate $<7$ or $>10 \mathrm{~mL} / \mathrm{min} / 1.73 \mathrm{~m}^{2}$ and anemia (hemoglobin $<100 \mathrm{~g} / \mathrm{L}$ ) at the initiation of dialysis are independently associated with the higher death risk. Using central venous catheter vascular access, cerebrovascular comor-
\end{abstract}

\section{KARGER}

(c) 2019 S. Karger AG, Basel

E-Mail karger@karger.com

www.karger.com/bpu bidities, diabetes, low-flux dialyzer, and dialysis frequency $\leq 2$ times weekly were also the independent risk factors of death within 48 months. Conclusions: This study indicated that the status of HD initiation is a risk factor of long-term survival in MHD patients, which were usually ignored for lacking of nephrology care prior and could potentially be identified and modified to improve the survival prognosis. Video JournalClub "Cappuccinowith Claudio Ronco" at https:// www.karger.com/Journal/ArticleNews/223997?sponsor=52

(c) 2019 S. Karger AG, Basel

\section{Background}

The incidence of end-stage renal disease (ESRD) has been increasing annually and has become a significant public health problem worldwide. In China, the prevalence and incidence of dialysis were 237.3 and 15.4 pmp in 2012 [1]. The latest and unpublished data from Chinese National Renal Data System (CNRDS) showed 
that in 2017, the number of patients receiving dialysis therapy was at least 596,365 , and $>85 \%$ was under hemodialysis (HD). The incidence was 80,000 per year from 2010 to 2017 . The annual mortality rate of maintenance HD (MHD) in Beijing ranged from 7.4 to $9.0 \%$ in 2009 [2], and it showed a declining trend and reached $6.4 \%$ in 2013 [3].

Increased attention to potentially modifiable factors, which are associated with an increased risk of death, has been spawned for the very high mortality of HD patients compared to health people. Strong associated predictors of outcome are age, race, anemia, mineral-bone disease, vascular access type, dose of dialysis, inflammation, nutrition, psychosis state, nonrenal comorbidity, and so on [4, 5]. Intensive emphasis on these risk factors has resulted in a significant improvement in patient survival, with the mortality among HD patients falling 2-3\% per year since 2001 [6]. However, the 4 -year mortality in HD patients is still unacceptably high, which indicates that other factors may be neglected. Among these factors, some of them may be far away from spotlight but may play an indispensable role in affecting the mortality of HD patients. We performed a retrospective study to investigate the risk factors of all-cause mortality which might be ignored in HD patients.

\section{Methods}

\section{Patient Selection}

In this retrospective study, we included adult patients ( $\geq 18$ years old) on MHD who died between January 1, 2012, and December $31,2016(n=121)$ at the HD center of Second Xiangya Hospital of Central South University. Patients on MHD are defined as receiving HD therapy for $>3$ months. Patients, who received renal transplantation, underwent switches from peritoneal dialysis to $\mathrm{HD}$, or received peritoneal dialysis and HD treatment meanwhile during the renal replacement treatment period were excluded.

The decision of study time span depended on the median survival time and the average survival time of the cohort. The study period and data collected were 48 months from starting of dialysis. The patients who survived $<48$ months on HD were identified as dead, and those who survived $\geq 48$ months on HD were identified as survived. We calculated the sample size according to the formula,

$$
\begin{aligned}
& n=\frac{u_{\alpha / 2}^{2} \pi(1-\pi)}{\delta^{2}} \\
& u_{\alpha / 2}^{2}=1.96
\end{aligned}
$$

$\delta=0.1, \alpha=0.05, \pi=0.6, n=92$. The sample size of our study is 117 . We collected date from $117 \mathrm{HD}$ patients and stratified these patients by survival time on $\mathrm{HD}$ ( $<48$ and $\geq 48$ months) [7].

Pre-Dialysis Condition Is Associated with

Mortality of MHD Patients
Data Sources

Data were obtained from CNRDS [available at: http://www. cnrds.net/www/html/index.html] (in Chinese) and in-patients clinic data system of the Second Xiangya Hospital of Central South University. CNRDS is a register system for dialysis patients in China.

The gathered data encompassed the baseline demographics (age, gender, and the date of HD initiation), primary disease (diabetic nephropathy or nondiabetic nephropathy), comorbidities (presence of hypertension, coronary vascular disease, peripheral vascular disease, cerebrovascular disease, chronic respiratory disease, heart failure, malignancy), laboratory tests before HD initiation, including body mass index and estimated glomerular filtration rate (eGFR) calculated by using the modification of diet in renal disease. Serum albumin, hemoglobin $(\mathrm{Hb})$, and whether the dialysis initiated unplanned/planned were recorded. Laboratory tests during maintenance dialysis period, including the average values of $\mathrm{Hb}$, serum albumin, serum phosphorus, intact parathyroid hormone, ferroprotein, and serum lipid, were also recorded. The dialysis treatment information including dialysis vascular access, dialyzer flux, dialysis frequency, and medicine therapy (angiotensin-converting enzyme inhibitor/angiotensin receptor blocker and $\beta$-receptor blocker) was also documented. The death information was obtained from the CNRDS, including date and cause of death.

\section{Statistical Analysis}

All statistical operations were performed using the Statistical Package for Social Sciences for windows 19.0 (SPSS Inc., Chicago, IL, USA). $t$ test for comparing the value of survival time of maintenance dialysis, $p \leq 0.05$. Pearson chi-square test was applied to compare the differences of demographic factors, primary renal disease, and cause of death. For evaluating the risk factors of allcause death within 48 months, the Kaplan-Meier method was used to analyze risk factors associated with death. Multivariate Cox regression was used to analyze the potential risk factors related to all-cause death, and death risk ( $<48$ months) was evaluated by hazard ratios (HR) and 95\% CI. $p<0.05$ was considered as statistically significant.

\section{Results}

\section{Characteristics of Subgroup Patients}

The study included 117 patients (37 female and 80 male), the average survival time of maintenance dialysis was $51.68 \pm 35.15$ months, and average age of initiation dialysis was 65.77 years. All the patients were divided into 2 groups depending on the survival time ( $<48$ and $\geq 48$ months). The number of patients who survived longer than 48 months was 59 , and the average survival time of maintenance dialysis was $78.98 \pm 27.56$ months. The number of those who survived shorter than 48 months was 58 , and the average survival time of maintenance dialysis was $23.9 \pm 13.59$ months. The shorter survival time patients ( $<48$ months) tended to be older ( $\geq 70$ years) than the longer survival time ( $\geq 48$ months) patients at the initiation of HD. There were no significant differ- 
Table 1. Distribution of general characteristics of different MHD patients groups divided by survival time

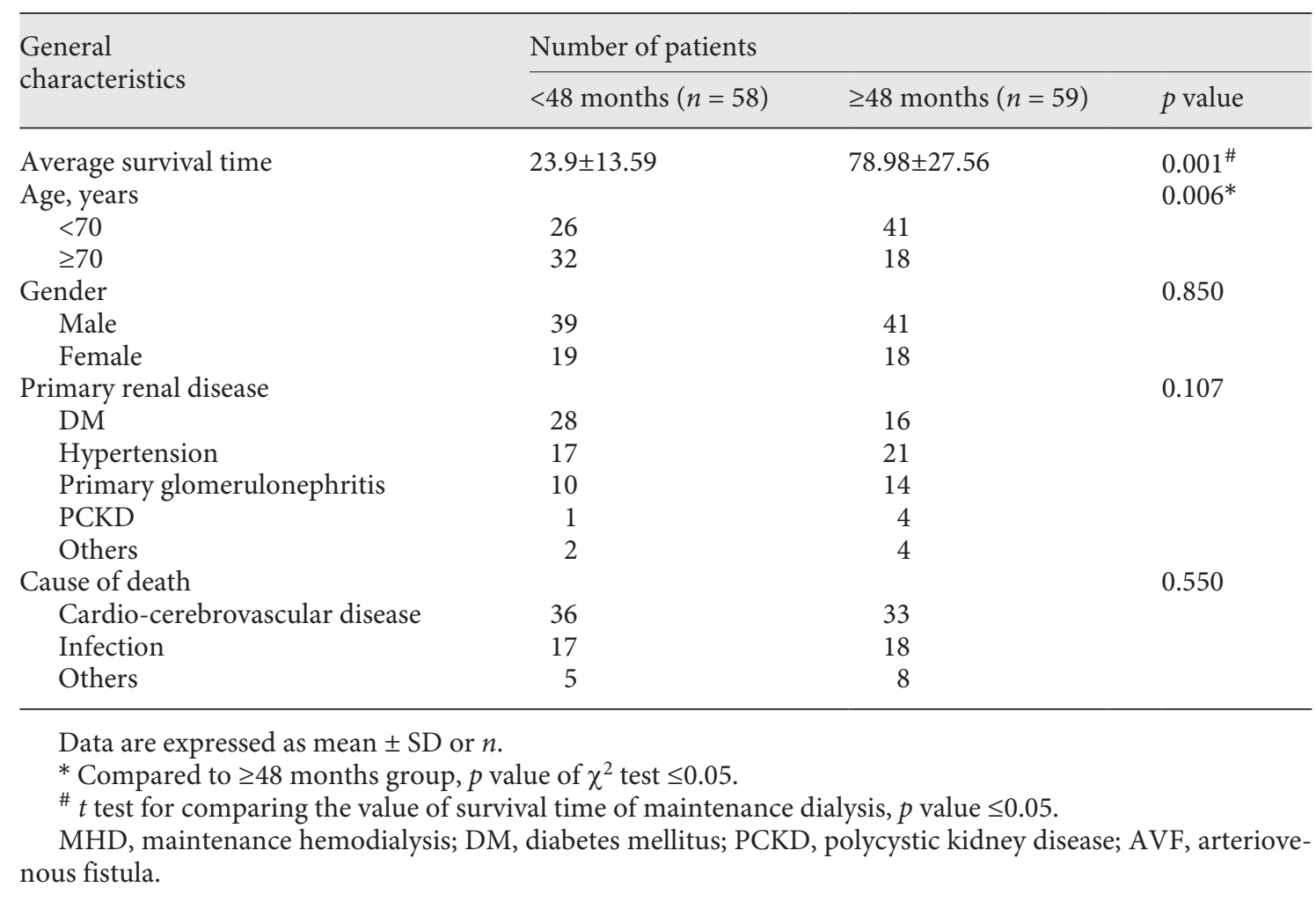

ences between these 2 groups with regard to gender, primary renal disease, and the cause of death. The most common primary renal diseases were diabetic nephropathy and hypertensive nephropathy, followed by primary glomerulonephritis, polycystic kidney disease, and others. Among those patients, the most common cause of death is cardio-cerebrovascular disease. Infection is also a very common cause of death in MHD patient (Table 1).

\section{Factors Associated with Survival in MHD Patients}

The Kaplan-Meier analysis was used to estimate the risk factors associated with $<48$ months survival in maintenance dialysis patients. Our results indicated that the diabetic nephropathy and cerebrovascular disease were risk factors of death. Furthermore, the baseline characteristics at HD initiation also affected the survival length of HD patients, low serum albumin concentration $(<30$ $\mathrm{g} / \mathrm{L})$, low $\mathrm{Hb}$ concentration $(<100 \mathrm{~g} / \mathrm{L})$, and baseline eGFR $<7 \mathrm{~mL} / \mathrm{min} / 1.73 \mathrm{~m}^{2}$ or eGFR $>10 \mathrm{~mL} / \mathrm{min} / 1.73 \mathrm{~m}^{2}$ at the initiation of $\mathrm{HD}$ were associated with short-time survival ( $<48$ months). More details are shown in Tables 2 and 3.
Compared with the HD-related factors, the patients who used central venous catheter (CVC), low-flux diayzer, with HD frequency less or equal than 2 times weekly, $\mathrm{Hb}<110 \mathrm{~g} / \mathrm{L}$, or been prescribed with $\beta$-receptor blocker had significantly shorter survival time ( $<48$ months; Table 4).

\section{Univariate Analysis of Death Risk}

As shown in Table 5 and Figures 1 and 2, univariate analysis showed that diabetes (HR 2.066, 95\% CI 1.232-3.465), cerebrovascular disease (HR 2.544, 95\% CI 1.511-4.283), serum albumin $<30 \mathrm{~g} / \mathrm{L}$ (HR 2.446, 95\% CI $1.448-4.132$ ) or $\mathrm{Hb}<100$ g/L (HR 3.820, 95\% CI 1.38310.556), baseline eGFR $<7 \mathrm{~mL} / \mathrm{min} / 1.73 \mathrm{~m}^{2}$ (HR 3.072, $95 \%$ CI $1.635-5.775)$ or eGFR $>10 \mathrm{~mL} / \mathrm{min} / 1.73 \mathrm{~m}^{2}(\mathrm{HR}$ $2.467,95 \%$ CI $1.245-4.888)$ at the initiation of $\mathrm{HD}$, using low-flux dialyzer (HR 2.094, 95\% CI 1.217-3.63), using CVC vascular access (HR 11.932, CI 95\% 5.038-28.263), HD frequency $\leq 2$ times weekly (HR 2.120, 95\% CI 1.2463.606), $\mathrm{Hb}<110 \mathrm{~g} / \mathrm{L}$ (HR 2.917, 95\% CI 1.595-5.334), and had not been prescribed with $\beta$-receptor blocker (HR 2.107 , 95\% CI 1.215-3.654) were closely associated with shorter survival time (<48 months; Fig. 1). 
Table 2. Kaplan-Meier analysis of clinic factors in MHD patients

\begin{tabular}{|c|c|c|c|}
\hline \multirow[t]{2}{*}{ Clinic factors } & \multicolumn{3}{|l|}{ Number of patients } \\
\hline & $<48$ months $(n=58)$ & $\geq 48$ months $(n=59)$ & $p$ value \\
\hline \multicolumn{4}{|l|}{ Primary disease } \\
\hline $\mathrm{DM}$ & 28 & 15 & \multirow{2}{*}{$0.005^{*}$} \\
\hline Non-DM & 30 & 44 & \\
\hline \multicolumn{4}{|l|}{ BMI, $\mathrm{kg} / \mathrm{m}^{2}$} \\
\hline$<18$ (reference) & 13 & 9 & \\
\hline $18-25$ & 35 & 42 & 0.070 \\
\hline$>25$ & 7 & 8 & 0.095 \\
\hline \multicolumn{4}{|l|}{ Comorbidities } \\
\hline \multicolumn{4}{|l|}{ Hypertention } \\
\hline No & 8 & 11 & \multirow[t]{2}{*}{0.859} \\
\hline Yes & 50 & 48 & \\
\hline \multicolumn{4}{|c|}{ Chronic respiratory disease } \\
\hline No & 45 & 42 & \multirow[t]{2}{*}{0.585} \\
\hline Yes & 13 & 17 & \\
\hline \multicolumn{4}{|l|}{ Heart failure } \\
\hline No & 38 & 42 & \multirow[t]{2}{*}{0.706} \\
\hline Yes & 20 & 17 & \\
\hline \multicolumn{4}{|c|}{ Cerebrovascular disease } \\
\hline No & 34 & 50 & \multirow[t]{2}{*}{$<0.001^{*}$} \\
\hline Yes & 24 & 9 & \\
\hline \multicolumn{4}{|c|}{ Peripheral vascular disease } \\
\hline No & 50 & 53 & \multirow[t]{2}{*}{0.312} \\
\hline Yes & 8 & 6 & \\
\hline \multicolumn{4}{|c|}{ Coronary vascular disease } \\
\hline No & 30 & 38 & \multirow[t]{2}{*}{0.290} \\
\hline Yes & 28 & 21 & \\
\hline \multicolumn{4}{|l|}{ Malignancy } \\
\hline No & 51 & 53 & \multirow[t]{2}{*}{0.972} \\
\hline Yes & 7 & 6 & \\
\hline
\end{tabular}

\section{Multivariate Analysis of Death Risk}

Based on the results from univariate analysis, further multivariate analyses revealed the interactions of these risk factors. The results exhibited that diabetes, cerebrovascular disease, baseline eGFR $<7 \mathrm{~mL} / \mathrm{min} / 1.73 \mathrm{~m}^{2}$ or eGFR $>10 \mathrm{~mL} / \mathrm{min} / 1.73 \mathrm{~m}^{2}, \mathrm{Hb}<100 \mathrm{~g} / \mathrm{L}$ at the initiation of HD, using low-flux dialyzer, CVC vascular access, HD frequency $\leq 2$ times weekly and had not been prescribe with $\beta$-receptor blocker were significant independent risk factors of shorter survival time ( $<48$ months). After adjusting age and gender, the predialysis status (eGFR and $\mathrm{Hb}$ ) seems one of the most important risk factors for HD patient survival. The results disclosed that baseline eGFR $<7 \mathrm{~mL} / \mathrm{min} / 1.73 \mathrm{~m}^{2}$ (HR 5.984, 95\% CI 2.941-12.176), using CVC vascular access (HR 4.402, 95\% CI 1.522-12.728), predialysis $\mathrm{Hb}<100$ g/L (HR
3.646, 95\% CI 1.292-10.293), cerebrovascular disease (HR 2.794, 95\% CI 1.570-4.973), baseline eGFR >10 mL/ $\mathrm{min} / 1.73 \mathrm{~m}^{2}$ at predialysis(HR2.633,95\% CI 1.278-5.548), diabetes (HR 2.589, 95\% CI 1.456-4.635), using low-flux dialyzer (HR 2.174, 95\% CI 1.130-4.184), and HD frequency $\leq 2$ times/week (HR 1.850, 95\% CI 1.031-3.322) were significant independent risk factors for all-cause death in MHD patients (Table 5, Fig. 2).

\section{Patients' Survival}

Kaplan-Meier survival curve is shown in Figure 3. Among patients whose predialysis $\mathrm{Hb} \geq 100 \mathrm{~g} / \mathrm{L}$ or baseline eGFR $7-10 \mathrm{~mL} / \mathrm{min} / 1.73 \mathrm{~m}^{2}$, the survival time was significantly longer than those whose $\mathrm{Hb}<100 \mathrm{~g} / \mathrm{L}(42.1$ vs. $80.0 \%, p=0.015$; a) or baseline eGFR $<7$ or $>10(29.0$ vs. 41.7 vs. $69.4 \%, p=0.001$; b). Note that the statistically 
Table 3. Kaplan-Meier analysis of pre-dialysis factors in MHD patients

\begin{tabular}{llll}
\hline Predialysis factors & \multicolumn{2}{l}{ Number of patients } \\
\cline { 2 - 3 } & $\begin{array}{l}<48 \text { months } \quad \geq 48 \text { months } \\
(n=58)\end{array} \quad \begin{array}{l}(n=59) \\
\end{array}$ \\
\hline
\end{tabular}

\begin{tabular}{lrrr}
$\begin{array}{l}\text { Serum albumin, g/L } \\
\quad<30\end{array}$ & 27 & 13 & $0.030^{*}$ \\
$\quad \geq 30$ & 31 & 46 & \\
$\mathrm{Hb}, \mathrm{g} / \mathrm{L}$ & & 42 & $0.005^{*}$ \\
$\quad<100$ & 54 & 17 & \\
$\quad \geq 100$ & 4 & 35 & $<0.001^{*}$ \\
$\begin{array}{l}\text { Baseline eGFR } \\
\quad 7-10 \text { (reference) }\end{array}$ & 14 & 13 & \\
$\quad<7$ & 27 & 11 & \\
$\quad>10$ & 17 & 37 & 0.451 \\
Initiation of dialysis & & 22 & \\
$\quad$ Unplanned & 40 & & \\
$\quad$ Planned & 18 & & \\
\hline
\end{tabular}

* $p$ value of Kaplan-Meier test $\leq 0.05$.

eGFR, estimated glomerular filtration rate $\left(\mathrm{mL} / \mathrm{min} / 1.73 \mathrm{~m}^{2}\right)$; MHD, maintenance hemodialysis; Hb, hemoglobin.

significant survival advantage of patients whose $\mathrm{Hb} \geq 100$ $\mathrm{g} / \mathrm{L}$ and eGFR $7-10 \mathrm{~mL} / \mathrm{min} / 1.73 \mathrm{~m}^{2}$ at initiation of HD $(n=11,9.4 \%)$ and the cumulative survival rate of the patients whose eGFR $<7$ or $>10$, and $\mathrm{Hb}<100 \mathrm{~g} / \mathrm{L}$ at the initiation of HD were the lowest ( $n=55,48.2 \% ; 32.7$ vs. 60.8 vs. $90.9 \%, p<0.001 ; c)$.

\section{Discussion}

In China, there are more and more oncoming ESRD patients forced to be treated with HD, which is considered as a modality of RRT for most ESRD patients. The present puzzle is that 4-year mortality in HD patients is still high despite technological progression and application of different HD techniques. In this study, we collected and analyzed the clinical information of MHD patients, the results showed that diabetic nephropathy, cerebrovascular disease co-morbidity, and HD factors (vascular access, HD frequency, and dialyzer) were independent factors influencing patient survival, which confirmed with other studies [8-19]. What's more, the predialysis condition (eGFR and $\mathrm{Hb}$ ) also affects long-term prognosis, which were previously thought to predict early mortality. This means that commence HD in an optimal timing is critical for improving long-term prognosis as well.
The ideal time to initiate HD is still controversial. The patients have substantially started HD earlier over the past 2 decades [20]. The patients who initiated HD at eGFR $>10 \mathrm{~mL} / \mathrm{min} / 1.73 \mathrm{~m}^{2}$ has increased from $12.5 \%$ in 1996 to $40.5 \%$ in 2012 [21]. But recently, more and more trials and clinical observational studies had questioned this trend [22-25]. According to the RCT trial IDEAL (Initiating Dialysis Early and Late) studied by Cooper et al. [26], the results showed that no significant differences were noted between early (eGFR was $5.0-7.0 \mathrm{~mL} / \mathrm{min}$ ) and late (eGFR was $10.0-15.0$ $\mathrm{mL} / \mathrm{min}$ ) starting HD therapy for cardiovascular death or nonfatal cardiovascular, all-cause mortality outcomes, quality of life, and so on. Wright et al. [27] also investigated the effect of the timing of starting $\mathrm{HD}$ on survival in HD patients in the United States. They discovered that earlier starting of HD was even associated with poor survival outcome. A meta-analysis [28] found that after increasing $1 \mathrm{~mL} / \mathrm{min} / 1.73 \mathrm{~m}^{2}$ in the eGFR at the beginning of dialysis, all-cause mortality would elevated by $3-4 \%$ after adjustment for comorbid conditions.

Here, our results showed that the patients with the level of eGFR $7-10 \mathrm{~mL} / \mathrm{min} / 1.73 \mathrm{~m}^{2}$ at $\mathrm{HD}$ initiation had the lowest mortality. A higher $\left(>10 \mathrm{~mL} / \mathrm{min} / 1.73 \mathrm{~m}^{2}\right)$ or lower $\left(<7 \mathrm{~mL} / \mathrm{min} / 1.73 \mathrm{~m}^{2}\right)$ eGFR was associated with higher mortality. The partial reason is that the patient initiated HD at higher eGFR usually reflects a poor general condition, especially the states of overhydration and even heart failure, and some specific characteristics including presence of other serious comorbidities [20,29, 30]. Only the fittest patients could tolerate long enough and initiate HD later. Moreover, the eGFR or any index based on creatinine (or urea) is hardly accurate to predict the real renal function [31]. Therefore, it is hard to say that starting HD with higher eGFR implies a good condition at predialysis phase. Furthermore, our results concluded that the patients starting HD with higher eGFR $(>10 \mathrm{~mL} / \mathrm{min} / 1.73$ $\left.\mathrm{m}^{2}\right)$ had better outcome than the lower eGFR $(<7 \mathrm{~mL} /$ $\left.\min / 1.73 \mathrm{~m}^{2}\right)$ patients. This may be because most of the patients who started with low eGFR $\left(<7 \mathrm{~mL} / \mathrm{min} / 1.73 \mathrm{~m}^{2}\right)$ had not received nephrologist reference or did not accept HD treatment until they obtained more severe symptoms or comorbidities which were associated with poor prognosis.

Lately, NKFKDOQI HD Adequacy Work Group has recommended that the decision to initiate maintenance dialysis therapy should be based primarily on the presence of symptomatic uremia, protein-energy wasting, metabolic abnormalities, and volume overload rather than on a
Wang/Yang/Yuan/Li/He/Liu/Liu/Zhou/ Chen/Liu/Peng/Liu 
Table 4. Kaplan-Meier analysis of dialysis factors in MHD patients

\begin{tabular}{|c|c|c|c|}
\hline \multirow[t]{2}{*}{ Dialysis factors } & \multicolumn{3}{|c|}{ Number of patients } \\
\hline & $\begin{array}{l}<48 \text { months } \\
(n=58)\end{array}$ & $\begin{array}{l}\geq 48 \text { months } \\
(n=59)\end{array}$ & $p$ value \\
\hline \multicolumn{4}{|l|}{ Dialyzer flux } \\
\hline Low-flux dialyzer & 20 & 11 & \multirow[t]{2}{*}{$0.006^{*}$} \\
\hline High-flux dialyzer & 38 & 48 & \\
\hline \multicolumn{4}{|l|}{ Vascular access } \\
\hline CVC & 7 & 0 & \multirow[t]{2}{*}{$<0.001^{*}$} \\
\hline AVF & 51 & 59 & \\
\hline \multicolumn{4}{|c|}{ Dialysis frequency (per week) } \\
\hline$\leq$ twice & 22 & 22 & \multirow[t]{2}{*}{$0.004^{*}$} \\
\hline$>$ twice & 36 & 37 & \\
\hline \multicolumn{4}{|l|}{$\mathrm{Hb}, \mathrm{g} / \mathrm{L}$} \\
\hline$<110$ & 44 & 24 & \multirow[t]{2}{*}{$0.02^{*}$} \\
\hline$\geq 110$ & 14 & 35 & \\
\hline \multicolumn{4}{|l|}{ Serum albumin, g/L } \\
\hline$<35$ & 27 & 19 & \multirow[t]{2}{*}{0.587} \\
\hline$\geq 35$ & 31 & 24 & \\
\hline \multicolumn{4}{|l|}{ Serum phosphorus } \\
\hline$\leq 1.78$ & 26 & 32 & \multirow[t]{2}{*}{0.128} \\
\hline$>1.78$ & 32 & 27 & \\
\hline \multicolumn{4}{|l|}{ iPTH, pg/ $\mu \mathrm{L}$} \\
\hline $150-300$ (reference) & 23 & 25 & \multirow[t]{3}{*}{0.143} \\
\hline$<150$ & 19 & 19 & \\
\hline$>300$ & 16 & 15 & \\
\hline \multicolumn{4}{|l|}{ Ferroprotein } \\
\hline$<500$ & 43 & 45 & \multirow[t]{2}{*}{0.972} \\
\hline$\geq 500$ & 15 & 14 & \\
\hline \multicolumn{4}{|l|}{$\mathrm{LDL}-\mathrm{C}, \mathrm{mmol} / \mathrm{L}$} \\
\hline$<3.12$ & 33 & 40 & \multirow[t]{2}{*}{0.092} \\
\hline$\geq 3.12$ & 25 & 19 & \\
\hline \multicolumn{4}{|l|}{$\mathrm{HDL}-\mathrm{C}, \mathrm{mmol} / \mathrm{L}$} \\
\hline$<1.04$ & 32 & 30 & \multirow[t]{2}{*}{0.736} \\
\hline$\geq 1.04$ & 26 & 29 & \\
\hline \multicolumn{4}{|l|}{$\mathrm{TC}, \mathrm{mmol} / \mathrm{L}$} \\
\hline$<2.9$ (reference) & 14 & 9 & \multirow[t]{3}{*}{0.971} \\
\hline $2.9-5.2$ & 32 & 35 & \\
\hline$>5.2$ & 12 & 15 & \\
\hline $\mathrm{TG}, \mathrm{mmol} / \mathrm{L}$ & & & \\
\hline$<1.71$ & 34 & 32 & 0.569 \\
\hline$\geq 1.71$ & 24 & 27 & \\
\hline ACEI/ARB & & & \\
\hline No & 35 & 33 & 0.521 \\
\hline Yes & 23 & 26 & \\
\hline$\beta$-receptor blocker & & & \\
\hline No & 19 & 9 & $0.006^{*}$ \\
\hline Yes & 39 & 50 & \\
\hline
\end{tabular}

${ }^{*} p$ value of Kaplan-Meier test $\leq 0.05$.

MHD, maintenance hemodialysis; AVF, arteriovenous fistula; $\mathrm{Hb}$, hemoglobin; CVC, central venous catheter; LDL-C, low-density lipoprotein-cholesterol; HDL-C, high-density lipoprotein-cholesterol; TC, total cholesterol; TG, triglyceride; ACEI, angiotensin-converting enzyme inhibitor; ARB, angiotensin receptor blocker. specific level of kidney function [32]. This recommendation is slightly different from the 2006 guideline, which recommended a specific eGFR cutoff of $15 \mathrm{~mL} / \mathrm{min} / 1.73$ $\mathrm{m}^{2}$ for those who need HD therapy, but the new guideline did not provide an eGFR threshold for HD therapy initiation.

Anemia is highly prevalent in CKD patients, reported in up to $50 \%$ of predialysis CKD patients, and most of them haven't received rHuEPO treatment [33]. The results of this study indicated that $83.5 \%$ patients started $\mathrm{HD}$ with $\mathrm{Hb}<100 \mathrm{~g} / \mathrm{L}$, and most of them were not treated with any drug to correct anemia. Furthermore, the lower $\mathrm{Hb}(<100 \mathrm{~g} / \mathrm{L})$ in initiation of $\mathrm{HD}$ is an independent risk factor affecting long-term prognosis.

Recently, several studies found that ESRD patients with low $\mathrm{Hb}$ in initiation of HD suffered higher early mortality [34]. In DKD patients, the lower $\mathrm{Hb}(<100 \mathrm{~g} / \mathrm{L})$ at referral to renal services before HD initiation also could predict death [35]. One of the important reasons is that the lower $\mathrm{Hb}$ is a risk factor of cardiovascular disease [36]. A study from Japan showed that lower $\mathrm{Hb}$ level is associated with growing cardiothoracic ratio enlargement in ESRD patients, and maintaining $\mathrm{Hb}$ level above $90 \mathrm{~g} / \mathrm{L}$ could help protect from cardiac remodeling during the predialysis phase [37].

Our results also showed that $48.2 \%$ patients who initiated $\mathrm{HD}$ with both low $\mathrm{Hb}(<100 \mathrm{~g} / \mathrm{L})$ and lower or higher eGFR $\left(<7\right.$ or $\left.>10 \mathrm{~mL} / \mathrm{min} / 1.73 \mathrm{~m}^{2}\right)$ had the lowest survival rate. A large part of these patients, due to late referral, have not started renal replacement treatment until electrolyte disturbances, malnutrition, volume overload, heart failure, or other complications are accompanied. They need urgent HD treatment, and a temporary catheter can increases the risk of catheter-related infections, leading to sepsis and even death. But the severe predialysis condition could be potentially modifiable. One of the most important strategies is early nephrologist care that can help patient manage their blood pressure, anemia, timely set up the vascular access and initiation HD treatment, and so on.

CKD patients who have not received adequate nephrology care prior to dialysis simply turn to a potentially sicker population of patients. Longer nephrology care prior to dialysis was associated with better first-year survival, higher albumin and $\mathrm{Hb}$ [39]. And other studies also showed that the late nephrologist referral is an independent risk factor for poor survival outcome on dialysis [40, 41]. The guidelines suggest that CKD patients should be assigned to the nephrologist for $>1$ year and be set up ad- 
Table 5. Cox regression analysis of predialysis and dialysis factors for survival times

\begin{tabular}{|c|c|c|c|}
\hline Covariates & $\begin{array}{l}\text { Univariate analysis } \\
\mathrm{HR}(95 \% \mathrm{CI})\end{array}$ & $\begin{array}{l}\text { Multivariate analysis } \\
\text { HR }(95 \% \text { CI })\end{array}$ & $\begin{array}{l}\text { Adjusted multivariate analysis } \\
\text { HR }(95 \% \text { CI })\end{array}$ \\
\hline \multicolumn{4}{|l|}{ Primary rental disease } \\
\hline DM & $2.066(1.232-3.465)^{*}$ & $2.618(1.472-4.656)^{*}$ & $2.589(1.456-4.635)^{*}$ \\
\hline \multicolumn{4}{|l|}{ Cerebrovascular disease } \\
\hline Yes & $2.544(1.511-4.283)^{*}$ & $2.857(1.631-5.062)^{*}$ & $2.794(1.570-4.973)^{*}$ \\
\hline \multicolumn{4}{|l|}{ Serum albumin } \\
\hline$<30 \mathrm{~g} / \mathrm{L}$ & $2.446(1.448-4.132)^{*}$ & No significant & No significant \\
\hline \multicolumn{4}{|l|}{ Baseline $\mathrm{Hb}$} \\
\hline$<100 \mathrm{~g} / \mathrm{L}$ & $3.820(1.383-10.556)^{*}$ & $3.722(1.319-10.496)^{*}$ & $3.646(1.292-10.293)^{*}$ \\
\hline \multicolumn{4}{|l|}{ Baseline eGFR } \\
\hline $7-10, \mathrm{~mL} / \mathrm{min} / 1.73 \mathrm{~m}^{2}$ & & Control & Control \\
\hline$<7$ & $3.072(1.635-5.775)^{*}$ & $5.873(2.920-11.814)^{*}$ & $5.984(2.941-12.176)^{*}$ \\
\hline$>10$ & $2.467(1.245-4.888)^{*}$ & $2.641(1.278-5.640)^{*}$ & $2.633(1.278-5.548)^{*}$ \\
\hline \multicolumn{4}{|l|}{ Dialyzer flux } \\
\hline low-flux dialyzer & $2.094(1.217-3.630)^{*}$ & $2.208(1.153-4.227)^{*}$ & $2.174(1.130-4.184)^{*}$ \\
\hline \multicolumn{4}{|l|}{ Vascular access } \\
\hline CVC & $11.932(5.038-28.263)^{*}$ & $4.171(1.483-11.730)^{*}$ & $4.402(1.522-12.728)^{*}$ \\
\hline \multicolumn{4}{|l|}{ Dialysis frequency } \\
\hline$\leq 2$ times/week & $2.120(1.246-3.606)^{*}$ & $1.863(1.039-3.340)^{*}$ & $1.850(1.031-3.322)^{*}$ \\
\hline \multicolumn{4}{|l|}{$\mathrm{Hb}, \mathrm{g} / \mathrm{L}$} \\
\hline$<110$ & $2.917(1.595-5.334)^{*}$ & No significant & No significant \\
\hline \multicolumn{4}{|l|}{$\beta$-Receptor blocker } \\
\hline No & $2.107(1.215-3.654)^{*}$ & $2.202(1.044-4.644)^{*}$ & $2.132(0.998-4.552)$ \\
\hline
\end{tabular}

${ }^{a}$ Adjusted for age and gender.

* $p$ value $<0.05$ by Cox regression analysis.

$\mathrm{HR}$, hazard ratio; $\mathrm{DM}$, diabetes mellitus; $\mathrm{Hb}$, hemoglobin; CVC, central venous catheter.

Fig. 1. HR values of univariate analysis for dialysis-relative factors. HR, hazard ratio; eGFR, estimated glomerular filtration rate; $\mathrm{Hb}$, hemoglobin; CVC, central venous catheters; DM, diabetes mellitus.

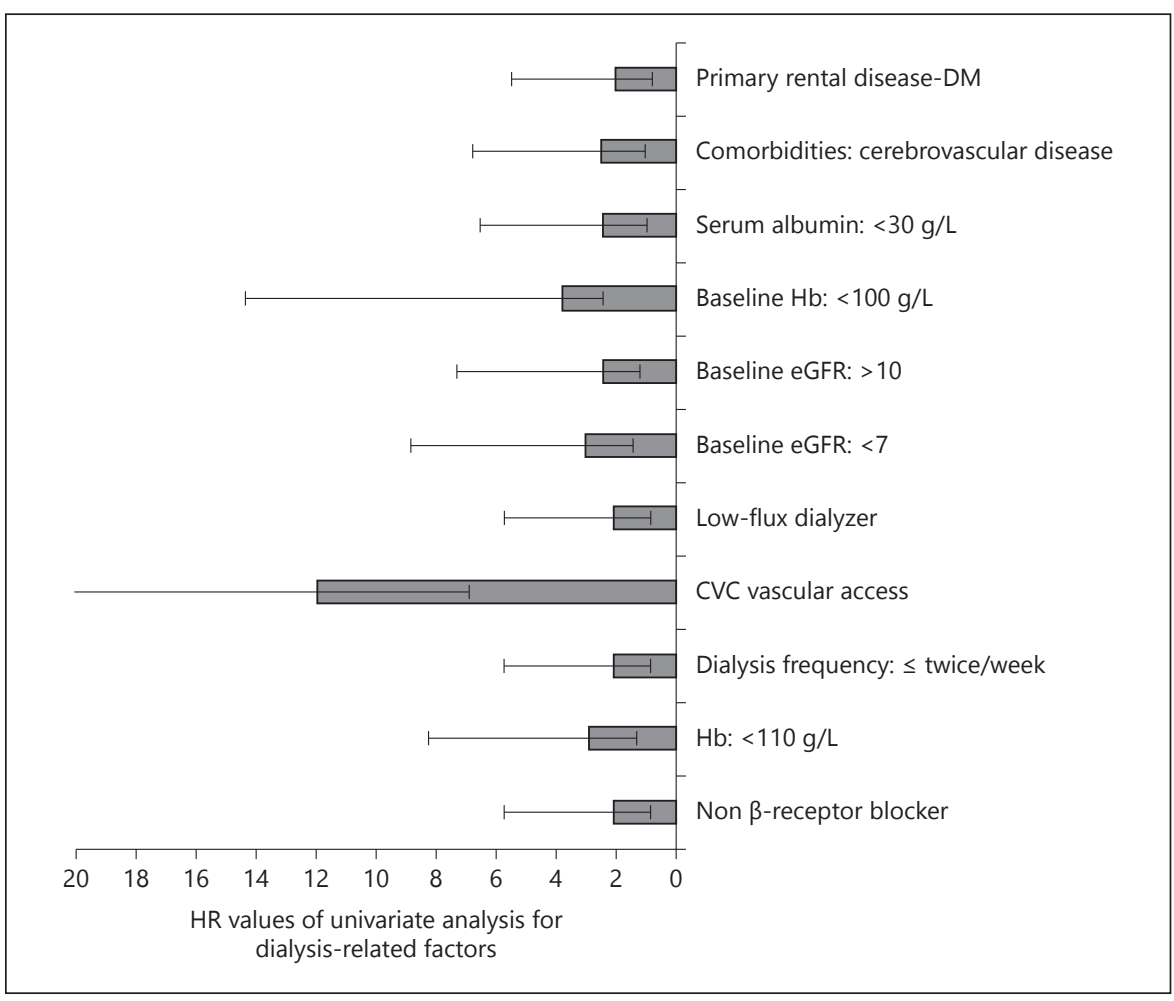

Wang/Yang/Yuan/Li/He/Liu/Liu/Zhou/ Chen/Liu/Peng/Liu 
Fig. 2. Adjusted $H R$ for predicting the higher death risk of $<48$ months. "No significant" indicates a no significant result after multivariate analysis by adjusting the factors of age and gender. DM, diabetes mellitus; $\mathrm{Hb}$, hemoglobin; eGFR, estimated glomerular filtration rate; CVC, central venous catheters; $\mathrm{HR}$, hazard ratio.

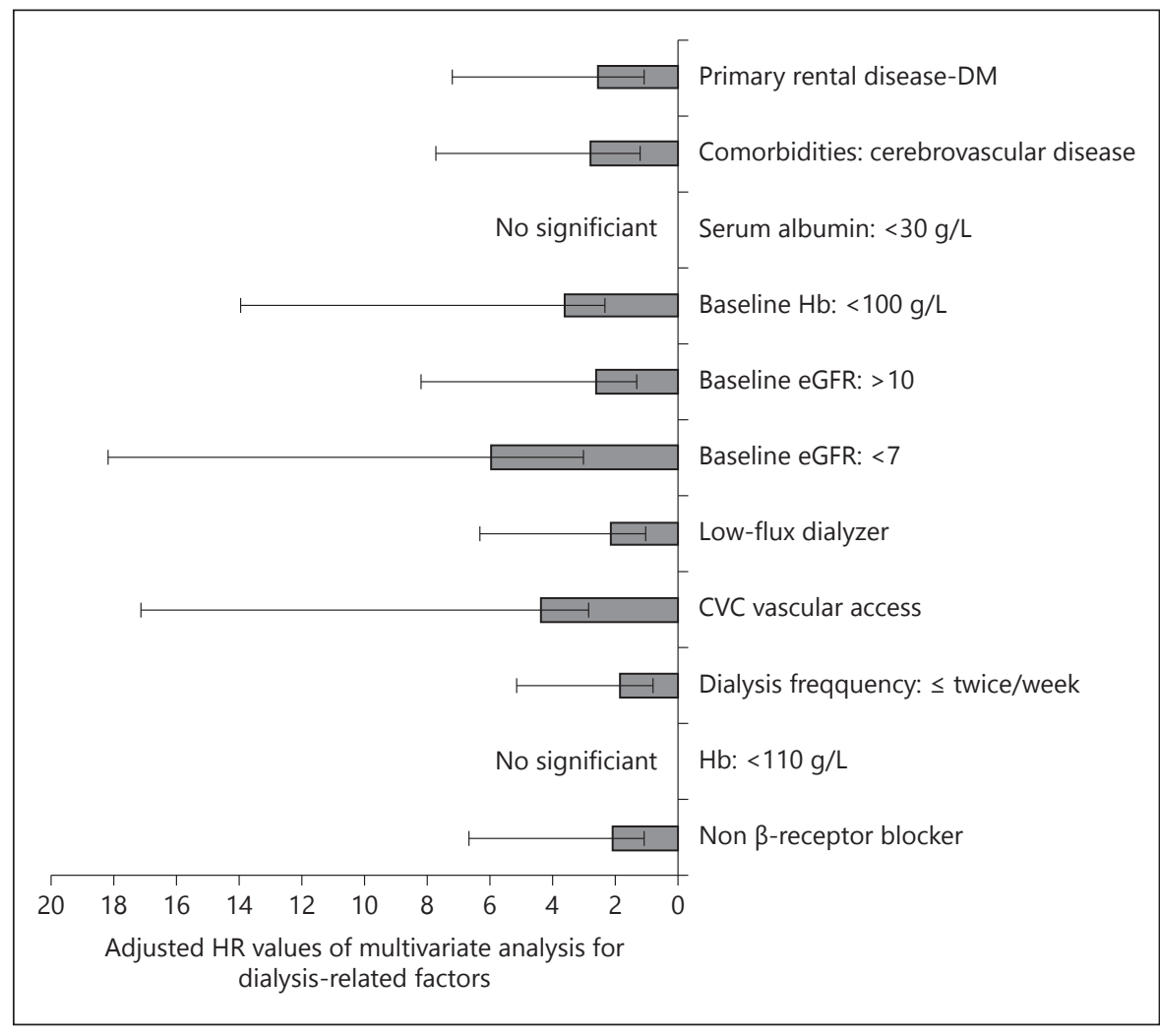

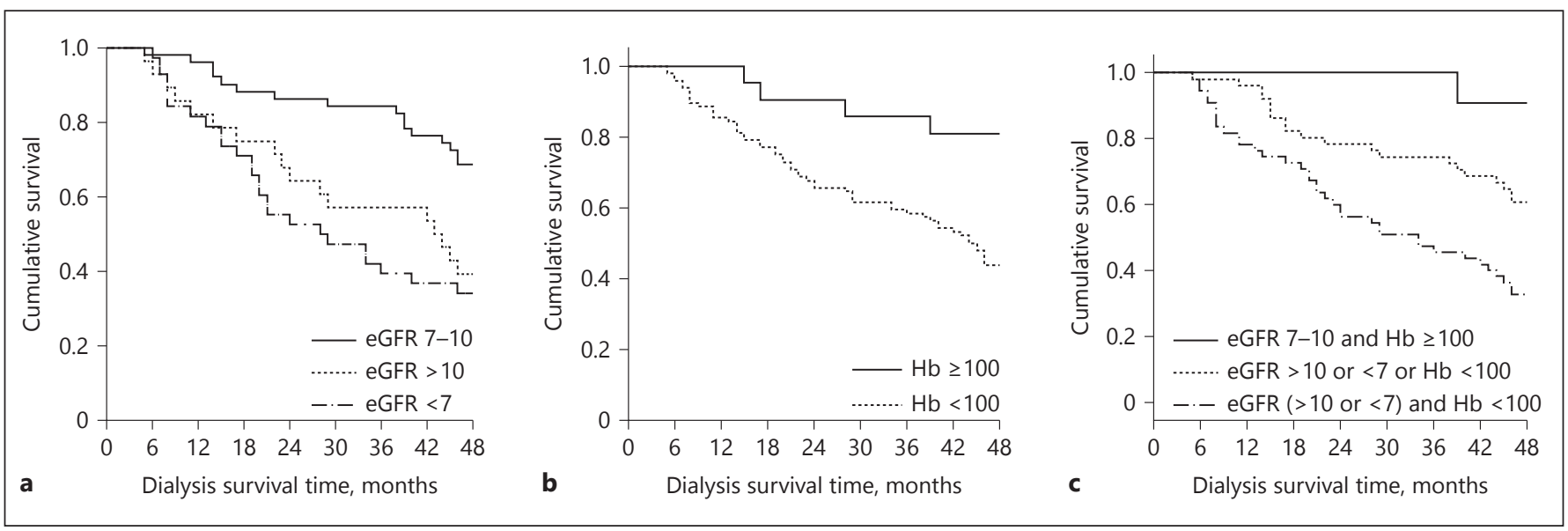

Fig. 3. Kaplan-Meier analysis for 48 months survival curves: (a) according to the eGFR at initiation of dialysis; (b) according to the $\mathrm{Hb}$ at initiation of dialysis; (c) according to the eGFR and $\mathrm{Hb}$ at initiation of dialysis. $\mathrm{Hb}$, hemoglobin; eGFR, estimated glomerular filtration rate.

equate vascular access up to 6 months before predicting dialysis.

For the anemia management, $\mathrm{rHuEPO}$ is one of the most effective prescriptions. A meta-analysis showed that $\mathrm{rHuEPO}$ treatment in predialysis patients correct- ed anemia, which could avoid blood transfusions requirement and improve life quality and exercise capacity [38]. A study indicated that patients who received multidisciplinary clinic care had higher level of $\mathrm{Hb}(102$ vs. $90 \mathrm{~g} / \mathrm{L}$ ) at dialysis starting and significantly better 
survival rate than standard nephrologist care patients [42].

Early nephrologist care prior to HD on uremic patients with symptoms, especially for active management of anemia, close monitoring of renal function changes, timely access to HD treatment on prognosis of patients will have a positive impact on long-term prognosis.

\section{Limitations of this Study}

In this study, we obtained some useful results, but the number of limitations still should be considered to the conclusions drawn. This is a single-center retrospective study. Cohort population is death MHD patients, and the initiation HD period was different, which might affect the prognosis. As the dataset in this study is relatively limited, the comprehensive analysis of more factors was not feasible, including blood pressure, indicator of inflammation status, HD ultrafiltration volume, and so on. Those are also affecting the prognosis of the MHD patients. Therefore, a large multicenter prospective study should be done to identify more potential independent risk factors.

\section{Conclusion}

In this study, we demonstrated that except for elderly age, diabetic nephropathy, cerebrovascular disease comorbidities, $\mathrm{HD}$ frequency $\leq 2$ times weekly, CVC vascular access, and low-flux dialyzer lead to the higher death risk of $<48$ months survive in MHD patients. What's more, the low concentration of $\mathrm{Hb}$ and too high or toolow eGFR at the initiation of HD indicated the poor survival prognosis as well. So those potentially modifiable factors in predialysis and dialysis stage provide a valuable intervention opportunity for improving the survival prognosis.

\section{Acknowledgments}

The authors grateful acknowledge the nephrologists and nurses from HD center of the Second Xiangya Hospital.

\section{Ethics Statement}

This study was conducted according to the guidelines laid down in the Declaration of Helsinki, and all procedures involving human subjects were approved by the Ethics Committee of the Second Xiangya Hospital of CSU. Ethic paper number: 2016 S099.

\section{Disclosure Statement}

The authors declare that they have no competing interests.

\section{Funding Source}

No application.

\section{Author Contributions}

C.W., H.-Q.L., L.-Y.H., D.L., Y.-X.L., and H.L.: collected the data. C.W. and Y.Y.: analyzed the data, and C.W. drafted the manuscript. F.Y., A.Z., X.C., F.-Y.L., and Y.-M.P.: discussed the results of the manuscript. H.L.: revised the manuscript and language. All authors reviewed and approved the final manuscript.

\section{Consent for Publication}

No application.

\section{Availability of Data and Materials}

The datasets used and/or analyzed during the current study are available from the corresponding author on reasonable request.

\section{References}

1 Zhang L, Zuo L. Current burden of end-stage kidney disease and its future trend in China. Clin Nephrol. 2016 Supplement 1;86 (2016) (13):27-28.

2 Zuo L, Wang M; for Beijing Blood Purification Quality Control and Improvement Center. Current status of maintenance hemodialysis in Beijing, China. Kidney Int Suppl (2011). 2013 May;3(2):167-9.

3 Gan L, Zuo L. Current ESRD burden and its future trend in Beijing, China. Clin Nephrol. 2015;83(7 Suppl 1):17-20.
4 Robinson BM, Bieber B, Pisoni RL, Port FK. Dialysis Outcomes and Practice Patterns Study (DOPPS): its strengths, limitations, and role in informing practices and policies. Clin J Am Soc Nephrol. 2012 Nov;7(11):1897-905.

5 Banerjee T, Kim SJ, Astor B, Shafi T, Coresh J, Powe NR. Vascular access type, inflammatory markers, and mortality in incident hemodialysis patients: the Choices for Healthy Outcomes in Caring for End-Stage Renal Disease (CHOICE) Study. Am J Kidney Dis. 2014 Dec;64(6):954-61.
6 Collins AJ, Foley RN, Gilbertson DT, Chen SC. United States Renal Data System public health surveillance of chronic kidney disease and end-stage renal disease. Kidney Int Suppl (2011). 2015 Jun;5(1):2-7.

7 Usvyat LA, Barth C, Bayh I, Etter M, von Gersdorff GD, Grassmann A, et al. Interdialytic weight gain, systolic blood pressure, serum albumin, and C-reactive protein levels change in chronic dialysis patients prior to death. Kidney Int. 2013 Jul;84(1): $149-57$. 
8 Canaud B, Tong L, Tentori F, Akiba T, Karaboyas A, Gillespie B, et al. Clinical practices and outcomes in elderly hemodialysis patients: results from the Dialysis Outcomes and Practice Patterns Study (DOPPS). Clin J Am Soc Nephrol. 2011 Jul;6(7):1651-62.

9 Sarnak MJ. Cardiovascular complications in chronic kidney disease. Am J Kidney Dis. 2003 Jun;41(5 Suppl):11-7.

10 Locatelli F, Del Vecchio L, Cavalli A. How can prognosis for diabetic ESRD be improved? Semin Dial. 2010 Mar-Apr;23(2):214-9.

11 Sozio SM, Armstrong PA, Coresh J, Jaar BG, Fink NE, Plantinga LC, et al. Cerebrovascular disease incidence, characteristics, and outcomes in patients initiating dialysis: the choices for healthy outcomes in caring for ESRD (CHOICE) study. Am J Kidney Dis. 2009 Sep;54(3):468-77.

12 Locatelli F, Martin-Malo A, Hannedouche T, Loureiro A, Papadimitriou M, Wizemann V, et al.; Membrane Permeability Outcome (MPO) Study Group. Effect of membrane permeability on survival of hemodialysis patients. J Am Soc Nephrol. 2009 Mar;20(3): 645-54.

13 Xue H, Ix JH, Wang W, Brunelli SM, Lazarus M, Hakim R, et al. Hemodialysis access usage patterns in the incident dialysis year and associated catheter-related complications. Am J Kidney Dis. 2013 Jan;61(1):123-30.

14 Pisoni RL, Arrington CJ, Albert JM, Ethier J, Kimata N, Krishnan M, et al. Facility hemodialysis vascular access use and mortality in countries participating in DOPPS: an instrumental variable analysis. Am J Kidney Dis. 2009 Mar;53(3):475-91.

15 Bieber B, Qian J, Anand S, Yan Y, Chen N, Wang M, et al. Two-times weekly hemodialysis in China: frequency, associated patient and treatment characteristics and Quality of Life in the China Dialysis Outcomes and Practice Patterns study. Nephrol Dial Transplant. 2014 Sep;29(9):1770-7.

16 Hornberger JC, Chernew M, Petersen J, Garber AM. A multivariate analysis of mortality and hospital admissions with high-flux dialysis. J Am Soc Nephrol. 1992 Dec;3(6):122737.

17 Port FK, Wolfe RA, Hulbert-Shearon TE, Daugirdas JT, Agodoa LY, Jones C, et al. Mortality risk by hemodialyzer reuse practice and dialyzer membrane characteristics: results from the usrds dialysis morbidity and mortality study. Am J Kidney Dis. 2001 Feb;37(2): 276-86.

18 Chauveau P, Nguyen H, Combe C, Chêne G, Azar R, Cano N, et al.; French Study Group for Nutrition in Dialysis. Dialyzer membrane permeability and survival in hemodialysis patients. Am J Kidney Dis. 2005 Mar;45(3):565-71.
19 Krane V, Krieter DH, Olschewski M, März W, Mann JF, Ritz E, et al. Dialyzer membrane characteristics and outcome of patients with type 2 diabetes on maintenance hemodialysis. Am J Kidney Dis. 2007 Feb;49(2):267-75.

20 O'Hare AM, Choi AI, Boscardin WJ, Clinton WL, Zawadzki I, Hebert PL, et al. Trends in timing of initiation of chronic dialysis in the United States. Arch Intern Med. 2011 Oct; 171(18):1663-9.

21 Saran R, Li Y, Robinson B, Ayanian J, Balkrishnan R, Bragg-Gresham J, et al. US Renal Data System 2014 Annual Data Report: Epidemiology of Kidney Disease in the United States. Am J Kidney Dis. 2015 Jul;66(1 Suppl 1):S1-305.

22 Korevaar JC, Jansen MA, Dekker FW, Jager KJ, Boeschoten EW, Krediet RT, et al.; Netherlands Cooperative Study on the Adequacy of Dialysis Study Group. When to initiate dialysis: effect of proposed US guidelines on survival. Lancet. 2001 Sep;358(9287):104650.

23 Lee J, An JN, Hwang JH, Kim YL, Kang SW, Yang CW, et al. Effect of dialysis initiation timing on clinical outcomes: a propensitymatched analysis of a prospective cohort study in Korea. PLoS One. 2014 Aug; 9(8):e105532.

24 Scialla JJ, Liu J, Crews DC, Guo H, BandeenRoche K, Ephraim PL, et al.; DEcIDE Network Patient Outcomes in End Stage Renal Disease Study Investigators. An instrumental variable approach finds no associated harm or benefit with early dialysis initiation in the United States. Kidney Int. 2014 Oct;86(4): 798-809.

25 Liberek T, Warzocha A, Galgowska J, Taszner $\mathrm{K}$, Clark WF, Rutkowski B. When to initiate dialysis-is early start always better? Nephrol Dial Transplant. 2011 Jul;26(7):2087-91.

26 Cooper BA, Branley P, Bulfone L, Collins JF, Craig JC, Fraenkel MB, et al.; IDEAL Study. A randomized, controlled trial of early versus late initiation of dialysis. N Engl J Med. 2010 Aug;363(7):609-19.

27 Wright S, Klausner D, Baird B, Williams ME, Steinman T, Tang $\mathrm{H}$, et al. Timing of dialysis initiation and survival in ESRD. Clin J Am Soc Nephrol. 2010 Oct;5(10):1828-35.

28 Susantitaphong P, Altamimi S, Ashkar M, Balk EM, Stel VS, Wright S, et al. GFR at initiation of dialysis and mortality in CKD: a meta-analysis. Am J Kidney Dis. 2012 Jun;59(6): 829-40.

29 Slinin Y, Guo H, Li S, Liu J, Morgan B, Ensrud $\mathrm{K}$, et al. Provider and care characteristics associated with timing of dialysis initiation. Clin J Am Soc Nephrol. 2014 Feb;9(2):310-7. 30 Treit K, Lam D, O’Hare AM. Timing of dialysis initiation in the geriatric population: to- ward a patient-centered approach. Semin Dial. 2013 Nov-Dec;26(6):682-9.

31 Leurs P, Machowska A, Lindholm B. Timing of dialysis initiation: when to start? Which treatment? J Ren Nutr. 2015 Mar;25(2):23841.

32 Daugirdas JT, Depner TA, Inrig J, Mehrotra R, Rocco MV, Suri RS, et al.; National Kidney Foundation. KDOQI Clinical Practice Guideline for Hemodialysis Adequacy: 2015 update. Am J Kidney Dis. 2015 Nov;66(5):884-930.

33 Szeto CC, Kwan BC, Chow KM, Pang WF, Leung CB, Li PK. Haemoglobin variability in Chinese pre-dialysis CKD patients not receiving erythropoietin. Nephrol Dial Transplant. 2011 Sep;26(9):2919-24.

34 Cherukuri A, Bhandari S. Analysis of risk factors for mortality of incident patients commencing dialysis in East Yorkshire, UK. QJM. 2010 Jan;103(1):41-8.

35 Joss N, Patel R, Paterson K, Simpson K, Perry C, Stirling C. Anaemia is common and predicts mortality in diabetic nephropathy. QJM. 2007 Oct;100(10):641-7.

36 Muhaisen RM, Sharif FA, Yassin MM. Risk factors of cardiovascular disease among children with chronic kidney disease in Gaza strip. J Cardiovasc Dis Res. 2012 Apr;3(2):918.

37 Asakawa T, Joki N, Tanaka Y, Hayashi T, Hase H, Komatsu Y, et al. Association between the Hemoglobin Level and Cardiothoracic Ratio in Patients on Incident Dialysis. Cardiorenal Med. 2014 Dec;4(3-4):189-200.

38 Cody JD, Hodson EM. Recombinant human erythropoietin versus placebo or no treatment for the anaemia of chronic kidney disease in people not requiring dialysis. Cochrane Database Syst Rev. 2016 Jan;1(1):157.

39 Gillespie BW, Morgenstern H, Hedgeman E, Tilea A, Scholz N, Shearon T, et al. Nephrology care prior to end-stage renal disease and outcomes among new ESRD patients in the USA. Clin Kidney J. 2015 Dec;8(6):772-80.

40 Schwenger V, Morath C, Hofmann A, Hoffmann O, Zeier M, Ritz E. Late referral-a major cause of poor outcome in the very elderly dialysis patient. Nephrol Dial Transplant. 2006 Apr;21(4):962-7.

41 Winkelmayer WC, Owen WF Jr, Levin R, Avorn J. A propensity analysis of late versus early nephrologist referral and mortality on dialysis. J Am Soc Nephrol. 2003 Feb;14(2): 486-92.

42 Curtis BM, Ravani P, Malberti F, Kennett F, Taylor PA, Djurdjev O, et al. The short- and long-term impact of multi-disciplinary clinics in addition to standard nephrology care on patient outcomes. Nephrol Dial Transplant. 2005 Jan;20(1):147-54. 